\title{
A new design approach for Süleyman Demirel University Botanical Garden
}

\author{
Şirin Dönmez ${ }^{a, *}$ (i), Nazlı Koçak ${ }^{a}$ (i), Mert Çakır ${ }^{a}$ (i)
}

\begin{abstract}
Botanical gardens were first established only for scientific reasons, however, later they have been started to be used for educational and recreation reasons. Since the 1980s it has been used to preserve natural resources and increase the biological variety. Botanical gardens are used as a tool all around the world to create environmental awareness, preserve natural resources and increase biological variety via educational activities. However, the botanical gardens which are important all over the world, are behind the world standards in Turkey when compared to other countries. However, 11.707 plant taxa including 3649 endemic varieties found in Turkey. Turkey seems to be richer in flora, compared with the continent of Europe, which is about 15 times larger than Turkey with 12,000 plant taxa. Turkey already deserves a sample equivalent to the botanical gardens in the world. Within the context of this study, Süleyman Demirel University Botanical Garden, which was started to establish in 1997 and not completed entirely, was determined as the study area. In the project, the main circulation system and the lateral roads reaching to the plant collections are not clearly perceived. There is no circulation hierarchy that visitors can follow. In addition, the botanical gardens are defined not only areas where collections are exhibited, but also areas where environmental consciousness and ecological awareness can be raised. So, new plan decisions were taken for Süleyman Demirel University Botanical Garden by using the data obtained from literature researches and field studies related to the Lakes Region, Isparta, and the study area. Within the framework of these plan decisions, a new design approach for Süleyman Demirel University Botanical Garden has been developed that includes plant collections such as healing garden, discovery garden, sensory garden, and local plant materials.
\end{abstract}

Keywords: Botanical garden, Isparta, Planting design, Thematic garden

\section{Süleyman Demirel Üniversitesi Botanik Bahçesi için yeni bir tasarım yaklaşımı}

Özet: Botanik bahçeleri, başlangıçta sadece bilimsel amaçlarla kurulan zamanla eğitsel ve rekreasyonel işlevlerin yanında 1980’li yıllardan itibaren doğal kaynakları koruma, biyoçeşitliliği artırma gibi görevleri de üstlenen kuruluşlardır. Dünyanın birçok ülkesinde eğitsel faaliyetlerle toplumun her kesiminde çevre bilinci oluşturulması, doğal kaynakların korunması ve biyoçeşitliliğin arttırılması konusunda botanik bahçeleri bir araç olarak kullanılmaktadır. Ancak bütün dünyada önem taşıyan botanik bahçeleri, Türkiye'de dünya standartlarının gerisinde kalmıştır. Oysaki 3649'u endemik, 11.707 civarında bitki taksonu bulunan Türkiye, 12.000 bitki taksonuna sahip kendisinden yaklaşık 15 kat büyük Avrupa kıtası ile kıyaslandığında flora bakımından daha zengin olduğu ve dünya örneklerine denk bir botanik bahçesini çoktan hak ettiği görülmektedir. Bu çalışma kapsamında 1997 yılında kuruluş çalışmalarına başlanan ve günümüze kadar tamamı tamamlanamayan Süleyman Demirel Üniversitesi Botanik Bahçesi çalışma alanı olarak belirlenmiştir. Projede ana sirkülasyon sistemi ve koleksiyon bahçelerine giden tali yollar net olarak algılanamamaktadır. Ziyaretçilerin takip edebileceği bir sirkülasyon hiyerarşisi bulunmamaktadır. Bunun yanı sıra, gelişen ve değişen botanik bahçesi kavramıyla, botanik bahçeleri yalnızca koleksiyonların sergilendiği alanlar değil, aynı zamanda çevre bilinci ve ekolojik farkındalığın yaratılabileceği aktivitelerin yer aldığı alanlar olarak da tanımlanmaktadır. Göller Yöresi, Isparta ve çalıșma alanı ile ilgili literatür araştırmaları ve arazi çalıșmalarından elde edilen verilerden yararlanılarak Süleyman Demirel Üniversitesi Botanik Bahçesi için yeni plan kararları alınarak içerisinde şifalı bahçe, keşif bahçesi, duyusal bahçe gibi bitki koleksiyonlarının ve yöreye özgü bitki materyalinin bulunduğu yeni bir tasarım yaklaşımı geliştirilmiştir.

Anahtar kelimeler: Botanik bahçesi, Isparta, Bitkisel tasarım, Tematik bahçe

\section{Introduction}

Botanical gardens are a part of the urban open-green space system and are the areas where biodiversity in the world is exhibited. According to the Botanic Gardens Conservation International, botanical gardens are organizations that hold documented living plants' collections for the purposes of scientific research, conservation, exhibition and education (Ward, et al., 2010).

Botanical gardens play a pioneering role in the development of plant taxonomy, systematic and horticulture. In the past, scientific studies have been carried out in botanical gardens such as plant-based medicines, economically important plants, and fruit trees. Today, however, the mission of many botanical gardens is focused on conservation of biodiversity and education (Donaldson, 2009; Williams, et al., 2015). The overall role of botanical gardens in plant protection has been widely accepted since the 1970s. And, today, documented living collections of many endangered plant species have been preserved in seed banks and botanical gardens (Oldfield, 2009). Since the 1990s, the global environmental agenda has focused on the destruction of species and the loss of biological diversity. Apart from its conservation function, botanical gardens

\footnotetext{
$\bowtie$ a Süleyman Demirel University, Faculty of Architecture, Department of Landscape Architecture, Isparta, Turkey

@ * Corresponding author (İletişim yazarı): sirindonmez@ sdu.edu.tr

$\checkmark \quad$ Received (Geliş tarihi): 24.10.2018, Accepted (Kabul tarihi): 21.03.2019
}

Citation (Atıf): Dönmez, Ș., Koçak, N., Çakır, M., 2018. A new design approach for Süleyman Demirel University Botanical Garden. Turkish Journal of Forestry, 20(1): 62-71. DOI: $10.18182 / \mathrm{tjf} .474236$ 
fulfill different functions in terms of scientific, educational and recreational. Botanical gardens are the gardens that focus on native plants in the region and conduct public education in response to the need to protect native plants.

In addition to its scientific mission, botanical gardens that respond the public space requirement are also an educational institution. Botanical gardens are important sources for the development of educational programs because they encourage people to think deeper about ecology, plants and their relationship. When considering public image and educational potential of these gardens, botanical gardens provide an opportunity to promote ecology to humans by fulfilling their functions as a link between the social environment and ecological systems (Kumble and Houston, 2009). Botanical gardens are not only areas of scientific research but also urban green spaces that respond to the recreational needs of the city residents. Botanical gardens allow the city residents to gain experience that affect their movements, behavior and social values by moving away from the daily stress of life with a relaxing natural environment (Willison, 1997, Var and Karaşah, 2010). Because botanical gardens carry scientific, educational and recreational functions together, they require a different planning and design from other parks and gardens. Conservation, education and scientific research functions should be adopted and multi-faceted approaches and planning decisions should be taken when botanical gardens are planning. And each garden should be planned and evaluated within its own special conditions (Konaklı, 2003).

Süleyman Demirel University Botanical Garden was designed and started to establish in 1997 in Isparta, Lakes Region. The existing plant material in the garden consists mainly of natural species collected from the Lake Region and species obtained as a result of the grant or donation. Plant materials in the botanical garden are located in arboretum, greenhouses (Greenhouse of Tropical Plants, Exhibition and Production of Native Plants), plots of evergreen and deciduous forest trees, medicinal and aromatic plants garden, rosarium (native and exotic rose varieties) systematic and geographical garden, geophyte (bulbous plants) garden, coniferous forests, natural and cultural ground covers, wild fruit trees garden, rock garden, fence and ivy plants, endemic plants (those grown only in Turkey), such as aquatic areas which are drawn in the architectural project (Özçelik et al., 2006).

When evaluated in line with the developing and changing design approach; the main circulation system of Süleyman Demirel University Botanical Garden project cannot be detected. In addition, areas where visitors can gain ecological awareness and perform recreational activities were found to be insufficient.

Within the scope of this work, it was aimed to develop a new design approach for Süleyman Demirel University Botanical Garden in the light of the field studies carried out on the sample area by examining the studies about botanical gardens from past to present day.

\section{Material and methods}

The main material is Süleyman Demirel University Botanical Garden, which is located in Isparta. Isparta, which is located between Burdur, Afyonkarahisar, Konya, and Antalya provinces in the Mediterranean Region and has a surface area of $8933 \mathrm{~km}^{2}$, lies between $30^{\circ} 20^{\prime}$ and $31^{\circ} 33^{\prime}$ East longitudes and $37^{\circ} 18^{\prime}$ and $38^{\circ} 30^{\prime}$ Northern latitudes. As a result of the long-term observations being examined in climatology terms, the characteristics of both climates can be seen in Isparta province, which is located in the transitional zone between Mediterranean and Continental climate. Due to the Mediterranean climate is seen in the south of the province, the summers are hot and dry while the winters are cold and rainy. The climate gets terrestrial as it goes northwards within the provincial borders (Anonymous, 2011).

Süleyman Demirel University Botanical Garden ( $37^{\circ} 50^{\prime}$ 40.37" $\mathrm{N}$ and $30^{\circ} 31^{\prime} 44.61^{\prime \prime} \mathrm{E}$ ) is located on the IspartaAnkara highway and located at approximately $11 \mathrm{~km}$ far away from Isparta city center. A total of 39 ha area were allocated for the Botanical Garden in 1996. For the botanical garden to be built on this area, the project was drawn by faculty members of Çukurova University Faculty of Agriculture Department of Landscape Architecture. Based on the first project, which is adapted to 26 ha by the Governorship, the project was drawn by the technical staff of Isparta Provincial Directorate of Public Works and Settlement. Approximately 800 plants are transferred to the garden, 170 of them are bulbous, 100 of them are medicinal and aromatic plants, 80 of them are wetland plants, about 50 of them are fruit trees and the rest of them are flowers and forest trees. Approximately 150 of these 800 plants were planted in the first establishment phase of the garden (Figure 1) (Özçelik et al., 2006). However, the project could not be applied except for the entrance section. The botanical garden, which was designed in 1996, has been out of date due to the changing design concept and the lack of direct access to plant collections.

A hierarchical order was established by changing the existing circulation and determining the main axis which circulates the whole area and lateral axis which circulates plant collections, within the scope of the study. Besides, botanical gardens are accepted not only as areas where the plant species are exhibited and protected, but also the areas where different themes are used. In this context, thematic areas such as sensory gardens and color gardens were designed by considering the plant collections.

Analysis sheets were prepared for the current situation in order to evaluate the works carried out in accordance with the preliminary project. For the evaluation of the current situation, site-specific climatic factors and vegetation texture, and the close environmental relations and transportation characteristics of the area were determined and transferred to analysis sheets. In addition, climatic data were also evaluated on the field in terms of directing the planning of SDU Botanical Garden. The consideration of climatic data in the framework of the new plan is particularly important in terms of planting design.

The soil of SDU Botanical Garden is clay in terms of texture, has a very high lime content, is salt-free, has a slightly alkaline property and the organic matter is low. The amount of potassium and calcium is very high, but the phosphorus is low. The amount of chemicals such as nitrogen, magnesium, copper, manganese, iron, and zinc in the soil is moderate. 


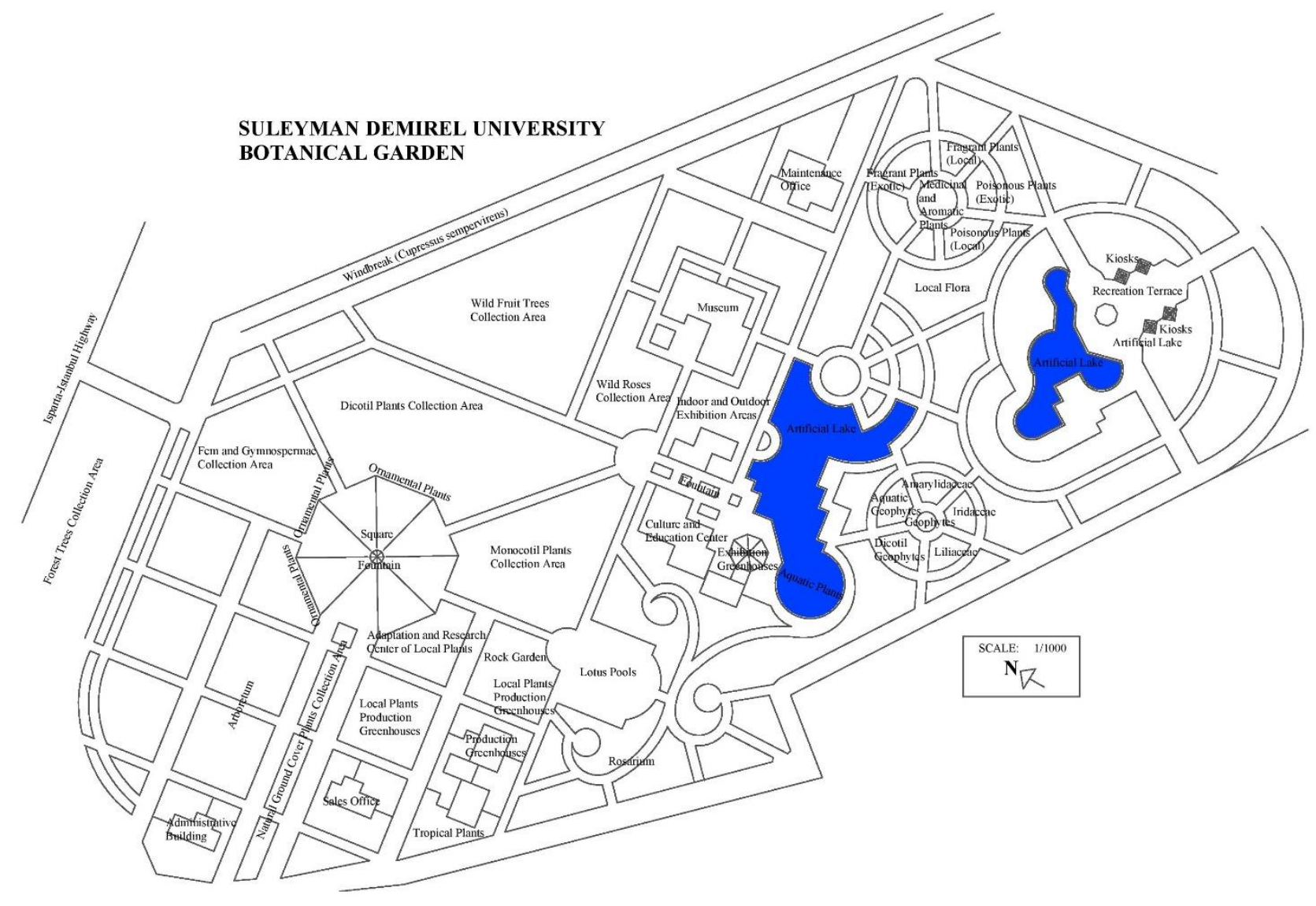

Figure 1. The landscape plan of Süleyman Demirel University Botanical Garden (Özçelik et al., 2006).

Studies, photographs, and projects on botanical gardens in the world and in Turkey have been used and examined. Topographical maps, geological maps, soil analyzes and the current plan of 1/1000 scale drawn by the technical staff of Isparta Provincial Directorate of Public Works and Settlement were used in the research area. The meteorological data obtained from the Provincial Meteorology Directorate has been taken into consideration in order to assist in planning. A new design approach has been developed by performing an area analysis in the direction of the obtained data.

\section{Results and discussion}

Site analyzes

As the infrastructure works are completed in the botanical garden, an unplanned planting is noticed. Plant groups in plant plots divided by roads and called arboretum, rock garden, medicinal and aromatic plants garden, systematic and geographical garden have not been planted in the garden considering a specific planting design. For example, although the arboretum in the garden contains woody plant species, no systematic or ecological scheme is observed.

It has also been found that the vast majority of plants in the botanical garden do not have label plates. Plant label plates which are resistant to external conditions and in standard sizes including information such as Latin and
Turkish name of species, origin, and date of planting, are very important in terms of introducing the plants. The absence of plant label plates does not serve the purpose of the establishment of the botanical garden.

It can be said that if the Botanical Garden is evaluated on the field studies, the existing plants are mostly planted without paying attention to the plant systematics and plant sociology. The field studies show that the existing plantation studies are intense in the completed parts of the substructure at the entrance of the area. Climatic factors and the analysis sheets showing the existing vegetation texture identified in botanical garden are given in Figure 2. One of the factors that are effective in the site selection and planning of botanical gardens is the relationship with the close environment. Factors such as the present settlement situation around the botanical garden, the possibility of encirclement with constructions in the near future, the presence of factory-like structures in the near future and water availability are very important in terms of planning.

Planning by evaluating the close environment of the SDU Botanical Garden will affect the design criteria in the botanical garden. According to field analysis, AnkaraIsparta highway is located to the west of the botanical garden and it is determined that it is a noise source for the area. Despite the presence of only the Technocity in the south and the Dormitories in the north, the botanical garden is adjacent to the campus of the university, indicating that it may be possible to construct new settlements in the near future due to the development of the university. For this 
reason, this possibility should be taken into consideration when creating a new plan.

Isparta Mensucat Inc., located in the north of the area, is a spinning factory established in 1987 and still operating. It has been determined with studies and surveys that the factory does not cause serious environmental pollution excluding noise and bad view source for the botanical garden. When a new plan is being developed, structural or planting solutions should be introduced that will prevent noise and bad view. When the transportation possibilities of SDU Botanical Garden are examined, it is seen that the botanical garden is about $11 \mathrm{~km}$ away from the city center and $28 \mathrm{~km}$ away from Süleyman Demirel Airport. The garden located on the Isparta-Ankara Highway can be easily reached by taxi or private vehicles. Public transport buses which go to the Dormitories in the north of the area passes in front of the botanical garden. If evaluated in terms of accessibility, SDU Botanical Garden, which is not far away from the city, is a place where public transportation can easily operate, visitors can easily reach the area.

When the vehicle and pedestrian circulation in the botanical garden is evaluated over the existing plan, it is seen that the circulation system is weak in terms of functionality and aesthetics. The circulation system in the garden is more of a cage texture, the transportation axes are perpendicular to each other and there are square or rectangular plant parcels among the axes. In the circulation system where the formal transport axes are located, the main axes and the lateral axis cannot be perceived clearly, the roads are not defined as vehicles or pedestrian circulation. In addition, the guidance characteristics of the axes providing direct or indirect access to the functions in the area are weak. Analysis of the close environment and transportation system of Süleyman Demirel University Botanical Garden are given in Figure 3.

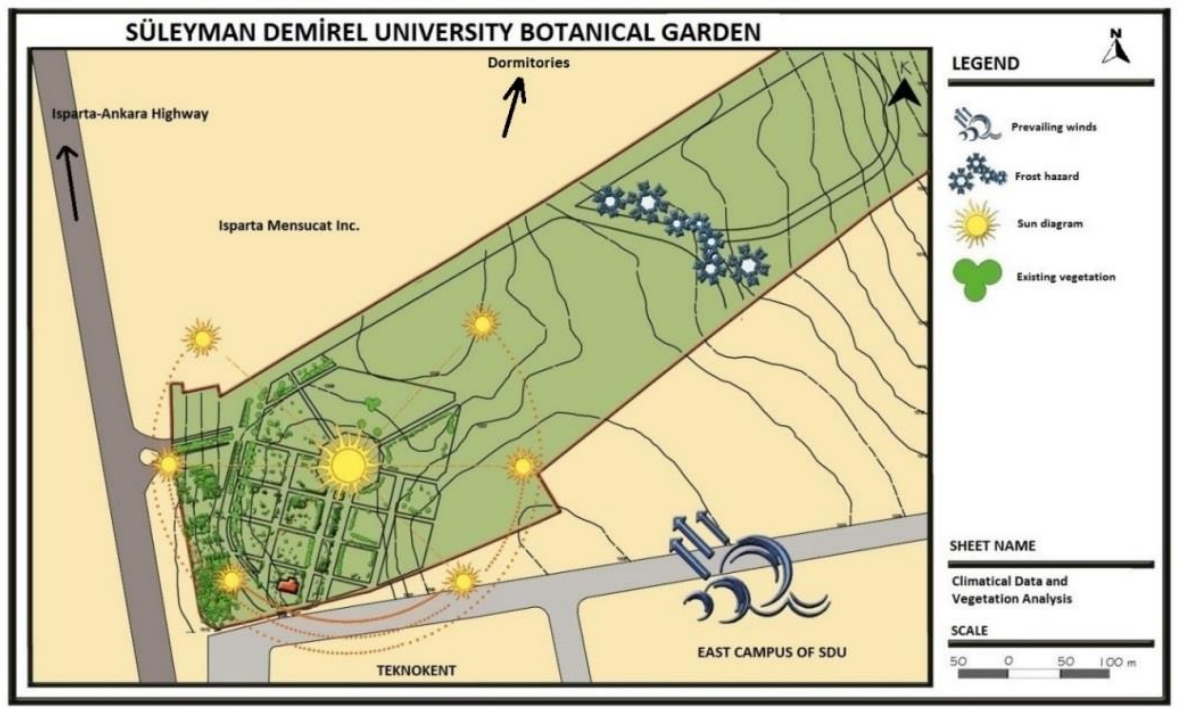

Figure 2. Climatic data and analysis of vegetation texture of SDU Botanical Garden

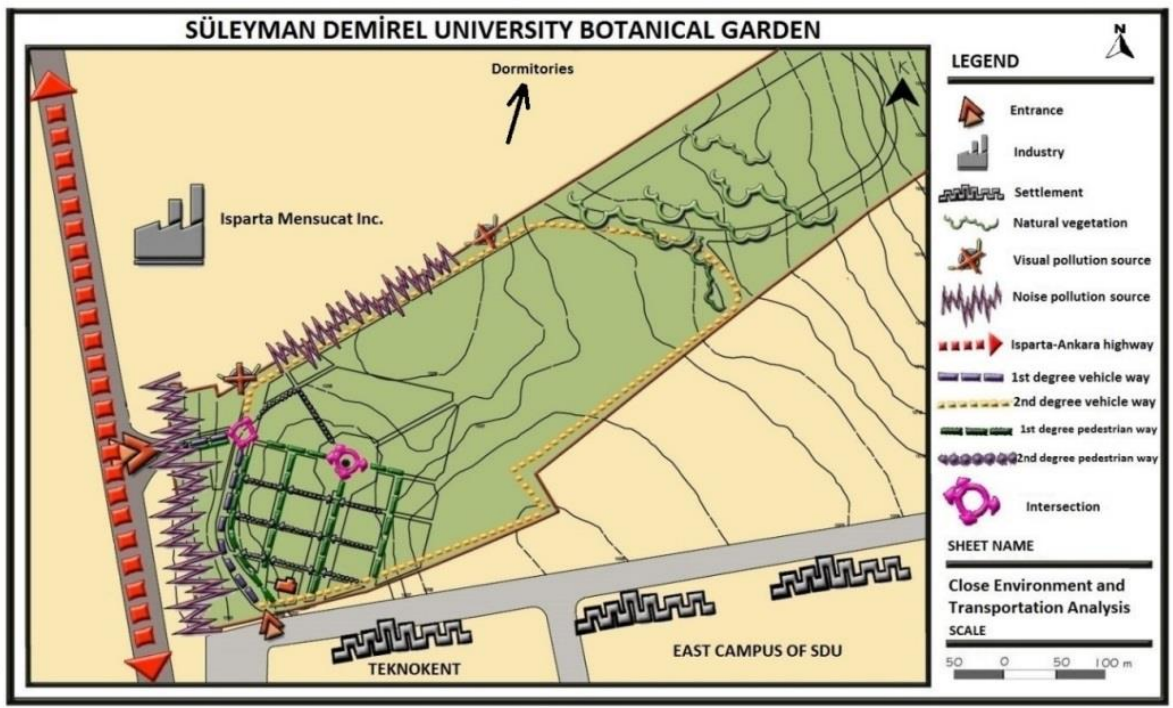

Figure 3. Analysis of close environment and transportation system of SDU Botanical Garden 


\subsection{Development of a new design approach for Süleyman Demirel University Botanical Garden}

A new design approach for a 26 ha garden area has been developed, taking into consideration area analyzes and the current situation of Süleyman Demirel University Botanical Garden and design features of the world's leading botanical gardens. The facilities that need to be found in SDU Botanical Garden can be grouped as entrance and parking lots, management building, education-research centers, recreational areas, plant collections, greenhouses and nurseries and water surfaces. In all these facilities within the botanical garden, plant collections are planned on different themes that are interesting to look at, with visual aesthetics and pleasant presentations, along with being based on scientific grounds.

Circulation System and of SDU Botanical Garden: New plan of Süleyman Demirel University Botanical Garden consists of the main circulation route which provides direct access to all the plant collections and two lateral roads which make it easy to see the plants in each collection. In addition, approximately $2 \mathrm{~km}$ of service road has been established in order to be used by garden staff and to enable visitors to access the parking lot in the entrance of the garden. The main road starting from the entrance in the northwest and the secondary entrance in the north of the area and extending in the northeast direction is $1.2 \mathrm{~km}$ long. One of the lateral roads is a seasonal circulation axis, which is 900-meter-long and connected to the main axis, forming an axis in itself and departing from the point where it intersects the main road coming from the entrances. The other is the thematic garden axis, which is about $1.6 \mathrm{~km}$ long, which goes out from two different points on the main road and lies between the different plant collections and intersect to the main road. The planned circulation system within the new project is given in Figure 4.

Plant collections and recreation areas in SDU botanical garden: New plan of Süleyman Demirel University Botanical Garden has been included in plant collections and recreation areas due to the circulation system. While locating the plant collections within the area, climatic factors, facilities in the immediate vicinity of the garden, and the purposes served by the plant collections are considered. In addition, plant collections are located by relating to each other and to the environment. The parking area near the main and secondary entrances is planned to serve the visitors and garden staff. The parking area, which is located on the edge of the Isparta-Ankara Highway may include shade trees and plant species that will create a noise barrier.

The first meeting area, which is in the entrance was planned as a rosarium. It was thought that it would reflect the economic importance as much as the aesthetic importance of Rose for Isparta. An ornamental pool is planned in the area where the circulation system intersects and form a center. This center is surrounded by healing garden, the collection of Lamiaceae, the collection of bulbous plant species, the collection of endemic and rare plants, lawns, and exhibition greenhouses. That is why it is important to draw attention to the important and valuable plant species of the Lake region, which forms the center of the botanical garden of these parts, and to ensure that these species are protected by cultivation. The aim is to draw attention to the important and valuable plant species of the Lake region which constitute the center of the botanical garden of these sections and to ensure that these species are protected by cultivation. In connection with the circulation system that goes through this center, plant collections are planned in different temples such as four-season garden, the collection of coniferous plants, discovery garden, sensory garden, aquatic garden and rock garden, respectively (Ünlü, 2016).

The thematic gardens and plant collections which exist in the concept plan are given below.

a) Rosarium: It is known that about 25 species of roses, which are thought to have 150-200 species growing naturally in the world, grow naturally in Turkey. Oil-bearing rose (Rosa damascena) production is made only in the Lakes Region for industrial purposes, in Turkey. For this reason, at the entrance to the Botanical Garden of SDU, Rosarium was preserved in order to emphasize the importance of the rose, which has an economic value and become the image of the city, rather than the visual value for Isparta. Table 1 shows a list of sample plants for Rosarium.

b) The collection of medicinal and aromatic plants (Healing Garden): A medicinal and aromatic plant garden that reflects the region should be planned in a botanical garden to be established in the Lakes Region which is rich in terms of medicinal and aromatic plants. Woody (Tilia $s p$., Rubus sp., etc.) and herbaceous (Mentha sp., Papaver sp., etc.) plants species are planned to be exhibited with the theme of 'Healing Garden' in the Botanical Garden of SDU (Table 2).

c) The collection of Lamiaceae: Lamiaceae family is one of the biggest and oldest families of the world and can be found in all habitat types. While it is represented by approximately 250 genus and 7000 species in the world, there are 46 genus and 755 taxa belonging to this family in Turkey (Hedge, 1992; Karabacak, 2009). The In addition to being an important center for biodiversity and endemism, the Lakes Region also has important species such as Salvia sp., Thymus sp., Origanum sp., and Lavandula sp. Therefore, planning was made with the necessity of creating Lamiaceae collection in a botanical garden to be established in this region. Table 3 shows a list of sample plants for Lamiaceae.

d) The collection of bulbous plants: Influenced by religious and ethnic diversity in Turkish culture, the flower culture which has emerged in its own way is quite developed. Thus, a period in the Ottoman state was called as 'Tulip Era'. The gardens, palaces, pavilions were planted with tulips in this era. 2718 bulbous plant species grow in the Lakes Region (Karakaş, 2007; Kılıçarslan and Dönmez, 2016). For this purpose, bulbous plant species collection is planned in the botanical garden. Some species that can be used in this garden are given in Table 4.

e) The collection of endemic and rare plants: The region is the Mediterranean region, which has a total of 3649 endemic plants of 11,707 taxa (species, subspecies, and variety). Approximately 750 endemic plant species are distributed in this region (Avc1, 2005). Isparta, which is located in the Lakes Region in the Mediterranean region, is also important in terms of plant diversity and the number of endemic species. Therefore, it will be important to 
understand the importance of the endemic species of the region and protection of this species by planting endemic plant species of Isparta and the Lakes Region dominantly in the collection of endemic plants in the botanical garden of SDU.

f) Four-season garden: This garden, which includes the seasonal circulation axis, is planned as a garden that will be enjoyed by people of all ages and which will be the excitement and curiosity of the four seasons. The basic principle in the planning of this garden is to draw attention to the visual impact and the changes in plants according to the seasons with spring, summer, autumn and winter gardens. It is thought that the compositions created with plants such as Acer spp., Quercus spp., Lagerstroemia indica, and Liriodendron tulipifera with attractive leaf colorations in autumn, Cercis siliquastrum, Magnolia spp., Forstyhia spp., Erica spp., and Rhododendron spp. with attractive flowers in spring and the conifers, which make the green dominant in the place the whole year, will have a different effect on the visitors depending on the season. Some suggested plants for Four-season Garden given in Table 5 .

g) The collection of coniferous plants: Close environment analysis and climatic data analysis were taken into consideration in the selection of the location for the coniferous collection in the garden area. An area was chosen for the collection of coniferous plants with an existing vegetation texture where the cold air can be absorbed and the danger of frost can be reduced and barriers, which prevent bad view and noise, can be placed between the botanical garden and Isparta Mensucat Inc. The main coniferous plants found in forests of Isparta are Pinus nigra subsp. pallasiana, Pinus brutia, Cedrus libani, Abies cilicica, Juniperus excelsa, and Juniperus oxycedrus subsp. oxycedrus (Anonymous, 2011). Establishing a coniferous plant collection in a botanical garden in Isparta is important in terms of reflecting the natural vegetation of the region and introducing the conifers which grown in the region (Table 6).

h) The discovery garden: The discovery garden is planned as a garden aiming to raise children and young people's awareness about plants, ecology and environmental protection with the focus of greening the urban environment through education, sustainable practices, and management. Thanks to this garden, children of all ages will discover habitats, recognize the mysterious world of plants, and learn about the wild life of the garden in a fun way. Children and young people will have access to more and more permanent information about the plants and at the same time receive practical training in fruit and vegetable gardens. Table 7 shows a list of sample plants for Lamiaceae.

I) The sensory garden: The sensory garden is planned to stimulate the five senses and includes selected plants and other design elements to offer visitors the experience of sight, smell, hearing, touch, and taste. The natural characteristics of the sensory garden are positioned and planned considering the relationship between the other plant collections planned in the botanical garden. For example; The aquatic garden in close to this garden supports the sensory garden in this direction by addressing hearing. In addition to plants that stimulate a single sense in the garden, plant species that stimulate several or all of the senses are also considered, such as Laurus nobilis, Pelargonium spp., Buddleja davidii. In Table 8, the species that can be used in this garden and the sense that it is directed is given.

j) The aquatic garden: The aquatic garden is a garden where water is formed in accordance with the planning and application techniques of the plants in accordance with the landscape characteristics of the area. It is inevitable to use the water element, the hydrophyt and the hygrophyt plant species in a botanical garden established in the Lakes Region, which takes its name from the lakes that are large and small (Table 9).

k) The rock garden: A rock garden was planned based on the field studies and the topographical structure of the area in the new plan of SDU Botanical Garden. The visual quality of the landscape will be increased with the rock garden, which will also benefit from the acoustic characteristics of the water. This rock garden is planned to break the effect of the cold air coming down from the slopes to the garden. Living and non-living materials in the alpine zone in the Lakes Region should be preferred in the establishment of the rock garden. Some suggested plants for The Rock Garden given in Table 10.

In addition, the observation terrace was created by using the difference in level in the area where the main road is over. An education and research area, which is located close to the university is planned in the south of the botanical garden. Why the education and research area is planned in this section is that it divides this area where scientific activities are carried out partly from the open sections of the garden. The concept plan of the Süleyman Demirel University Botanic Garden is shown in Figure 4.

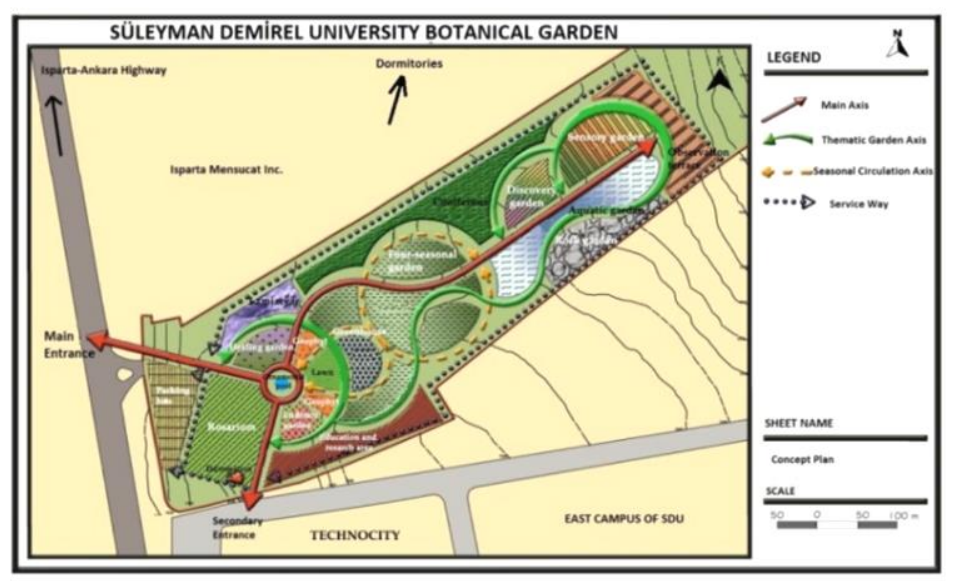

Figure 4. Concept plan of SDU Botanical Garden 
Table 1. Some suggested plants for Rosarium

\begin{tabular}{lll}
\hline Latin name & Latin name & Latin name \\
\hline Rosa agrestis & Rosa gallica x canina & Rosa phoenicia \\
Rosa arvensis & Rosa heckeliana & Rosa phoenicia arvensis \\
Rosa arvensis $x$ phoenicia & Rosa heckeliana subsp. orientalis & Rosa pimpinellifolia \\
Rosa beggeriana & Rosa hemisphaerica & Rosa pisiformis \\
Rosa damascena & Rosa hirtissima & Rosa pulverulenta \\
Rosa dumalis & Rosa horida & Rosa sempervirens \\
Rosa dumalis var. antalyensis & Rosa iberica & Rosa sicula \\
Rosa dumalis var. boissieri & Rosa jundzillii & Rosa tomentosa \\
Rosa elymaitica & Rosa micrantha & Rosa villosa subsp. millosa \\
Rosa foetida & Rosa montana & Rosa villosa subsp. villosa \\
Rosa foetida $x$ hemisphaerica & Rosa multiflora & \\
Rosa gallica & Rosa odorata & \\
\hline
\end{tabular}

Table 2. Some suggested plants for Healing Garden

\begin{tabular}{lll}
\hline Latin name & Latin name & Latin name \\
\hline Achillea sp. & Helichrysum $\mathrm{sp}$. & Pimpinella sp. \\
Anthemis sp. & Juniperus sp. & Pistacia terebinthus \\
Ballota sp. & Laurus nobilis & Plantago sp. \\
Calamintha sp. & Lavandula officinalis & Ruscus aculeatus var. angustifolius \\
Cerotonia sliqua & Malva sp. & Rosmarinus officinalis \\
Cichorium intybus & Melissa officinalis & Rubus sp. \\
Cistus sp. & Mentha sp. & Salvia sp. \\
Digitalis sp. & Ocimum basilicum & Thymus sp. \\
Echinophora tournefortii & Origanum sp. & Tilia sp. \\
Epilobium sp. & Papaver sp. & Ziziphus jujuba \\
Gysophila sp. & Rhus coriaria & \\
\hline
\end{tabular}

Table 3. Some suggested plants for the Collection of Lamiaceae

\begin{tabular}{lll}
\hline Latin name & Latin name & Latin name \\
\hline Clinopodium vulgare & Nepeta $\mathrm{sp}$. & Scutellaria sp. \\
Cyclotrichium origanifolium & Origanum $\mathrm{sp}$. & Sideritis sp. \\
Lamium sp. & Phlomis $\mathrm{sp}$. & Stachys $\mathrm{sp}$. \\
Marrubium sp. & Prasium majus & Teucrium sp. \\
Mentha spicata subsp. tomentosa & Prunella orientalis & Thymus sp. \\
Micromeria cristata subsp. Phrygia & Salvia sp. & Ziziphora clinopodioides \\
\hline
\end{tabular}

Table 4. Some suggested plants for the Collection of Bulbous Plant Species

\begin{tabular}{lll}
\hline Latin name & Latin name & Latin name \\
\hline Allium $\mathrm{sp}$. & Fritillaria $\mathrm{sp}$. & Orchis sp. \\
Anacamptis pyramidalis & Gagea $\mathrm{sp}$. & Ornithogalum montanum \\
Barlia robertiana & Galanthus $\mathrm{sp}$. & Pancratium maritimum \\
Bellevalia sp. & Gladiolus $\mathrm{sp}$. & Romulea sp. \\
Bellevalia trifoliata & Hyacinthella heldreichii & Scilla sp. \\
Chionodoxa forbesii & Lilium candidum & Serapias sp. \\
Colchicum sp. & Merendera sp. & Sternbergia sp. \\
Crocus sp. & Muscari $\mathrm{sp}$. & Tulipa sp. \\
Cyclamen $\mathrm{sp}$. & Narcissus $\mathrm{sp}$. & Urginea maritima \\
Dactylorhiza $\mathrm{sp}$. & Ophrys $\mathrm{sp}$. & \\
\hline
\end{tabular}

Table 5. Some suggested plants for Four-season Garden

\begin{tabular}{lll}
\hline Latin name & Highlights & Season \\
\hline Abelia sp. & Flower & Summer \\
Abies sp. & Form and color & Autumn/Winter \\
Acer sp. & Leaf & Spring/Summer/Autumn \\
Aesculus sp. & Flower & Spring \\
Albizzia julibrissin & Form and flower & Summer \\
Berberis sp. & Leaf & Summer/Autumn \\
Betula sp. & Form and trunk & Spring/Summer/Autumn/Winter \\
Buddleia davidii & Flower & Summer \\
Catalpa sp. & Form and flower & Spring/Summer \\
Cedrus sp. & Form and color & Autumn/Winter \\
Cercis sp. & Flower and fruit & Spring/Summer/Autumn \\
Chaenomeles sp. & Flower & Spring \\
Cornus sp. & Trunk and leaf & Autumn/Winter \\
Euonymus sp. & Leaf & Spring/Summer/Autumn \\
Forsythia sp. & Flower & Spring \\
Hibiscus syriacus & Flower & Summer \\
Hydrangea sp. & Flower & Summer \\
Juniperus sp. & Form and color & Autumns/Winter \\
Koelreuteria sp. & Flower & Summer/Autumn \\
\hline
\end{tabular}


Table 5. (continued)

\begin{tabular}{|c|c|c|}
\hline Latin name & Highlights & Season \\
\hline Lagerstroemia indica & Flower, leaf and trunk & Summer/Autumn \\
\hline Liriodendron tulipera & Flower and form & Summer/Autumn \\
\hline Malus sp. & Flower & Spring \\
\hline Nandina domestica & Leaf & Autumn \\
\hline Quercus sp. & Form and leaf & Summer/Autumn \\
\hline Parthenocissus sp. & Leaf and color & Autumn \\
\hline Picea sp. & Form and color & Autumn/Winter \\
\hline Pinus sp. & Form and color & Autumn/Winter \\
\hline Platanus sp. & Form and leaf & Summer/Autumn \\
\hline Prunus sp. & Leaf & Spring/Summer/Autumn \\
\hline Pyracantha sp. & Fruit & Autumn/Winter \\
\hline Rhus sp. & Leaf and color & Autumn \\
\hline Salix sp. & Form & Spring/Summer/Autumn \\
\hline Sophora japonica & Form & Summer/Autumn \\
\hline Spirea sp. & Form and flower & Spring \\
\hline Syringa sp. & Flower & Spring \\
\hline Sytrax officinalis & Flower and leaf & Summer/Autumn \\
\hline Tamarix sp. & Flower & Summer/Autumn \\
\hline Thuja sp. & Form and color & Spring \\
\hline Viburnum sp. & Flower and leaf & Summer/Autumn/Winter \\
\hline Weigela floribunda & Flower & Spring \\
\hline Wisteria sinensis & Flower & Spring \\
\hline
\end{tabular}

Table 6. Some suggested plants for the Collection of Coniferous Plants

\begin{tabular}{ll}
\hline Latin name & Latin name \\
\hline Abies cilica subsp. cilicica & Juniperus oxycedrus subsp. macrocarpa \\
Abies cilica subsp. isaurica & Juniperus oxycedrus subsp. oxycedrus \\
Cedrus libani & Juniperus oxycedrus subsp. oxycedrus var.oxyce \\
Cedrus libani var. libani & Juniperus sabina \\
Cupressus sempervirens & Pinus brutia var.brutia \\
Juniperus communis var. saxatalis & Pinus brutia var.pendulifolia \\
Juniperus drupacea & Pinus nigra \\
Juniperus excelsa & Pinus nigra subsp. pallasiana \\
Juniperus excelsa subsp. excelsa & Pinus nigra subsp. pallasiana var. fastigiata \\
Juniperus foetidissima & Pinus nigra subsp. pallasiana var. seneriana \\
Juniperus oxycedrus & Pinus pinea
\end{tabular}

Juniperus oxycedrus Pinus pinea

Table 7. Some suggested plants for The Discovery Garden

\begin{tabular}{|c|c|c|c|}
\hline Latin name & & Latin name & \\
\hline Abies cilicica & & Myriophyllum verticillatum & \\
\hline Alisma gramineum & & Nuphar lutea & \\
\hline Arenaria leptocladus & & Nymphaea alba & \\
\hline Astragalus micropterus & & Pinus nigra subsp. pallasiana & \\
\hline Astragalus mesogitanus & & Pistacia terebinthus & \\
\hline Astragalus plumosus & & Poa bulbosa & \\
\hline Bellis perennis & & Polygonum amphibium & \\
\hline Campanula involucrata & & Polygonum lapathifolium & \\
\hline Campanula stricta & & Potamogeton crispus & \\
\hline Carex halleriana & & Potamogeton lucens & \\
\hline Cedrus libani & & Potentilla reptans & \\
\hline Cistus laurifolius & & Ranunculus repens & \\
\hline Crataegus monogyna & & Ranunculus sceleratus & \\
\hline Cyperus longus & & Ranunculus trichophyllus & \\
\hline Cyperus rotundus & & Rosularia chrysantha & \\
\hline Dianthus anatolicus & & Rumex crispus & \\
\hline Equisetum arvense & & Rumex patientia & \\
\hline Equisetum ramossissium & & Quercus cerris & \\
\hline Inula heterolepis & & Quercus coccifera & \\
\hline Juniperus excelsa & & Quercus libani & \\
\hline Juniperus foetidissima & & Sedum album & \\
\hline Juniperus oxycedrus subsp. oxycedrus & & Sedum amplexicaule & \\
\hline Lythrum salicaria & & Typha angustifolia & \\
\hline Latin name & $\frac{\text { he Sens }}{\text { Sense }}$ & Latin name & Sense \\
\hline Abelia grandiflora & Smell & Origanum spp. & Smell and taste \\
\hline Briza media & Hearing & Pelargonium spp. & Smell and touch \\
\hline Buddleia davidii & Smell, sight & Phlomis fruticus & Touch \\
\hline Celtis australis & Taste & Philadelphus spp. & Smell \\
\hline Celtis caucasica & Taste & Populus tremula & Hearing \\
\hline Celtis glabrata & Taste & Prunus spp. & Taste \\
\hline Cerasus avium & Taste & Phyllostachy bambusoides & Hearing \\
\hline
\end{tabular}


Table 8. (continued)

\begin{tabular}{|c|c|c|c|}
\hline Latin name & Sense & Latin name & Sense \\
\hline Cupressus macrocarpa & Smell and touch & Punica spp. & Taste \\
\hline Cornus mas & Taste & Pyrus spp. & Taste \\
\hline Crateagus spp. & Taste & Rosmarinus officinalis & Smell and taste \\
\hline Cydonia spp. & Taste & Rubus "black satin" & Taste \\
\hline Eleagnus spp. & Smell and taste & Rubus idaeus & Taste \\
\hline Fragaria vesca & Taste & Salvia spp. & Smell, taste and touch \\
\hline Juniperus foetdissima & Smell & Santolina chamaecyparissus & Smell \\
\hline Laurus nobilis & Smell and taste & Syringa spp. & Smell and sight \\
\hline Lavandula officinalis & Smell & Stachys byzantina & Touch \\
\hline Lonicera spp. & Smell & Styrax officinalis & Smell \\
\hline Mentha spp. & Smell and taste & Sempervivum ispartae & Touch \\
\hline Morus spp. & Taste & Sempervivum pisidicum & Touch \\
\hline Nigella damascene & Hearing & Thymus spp. & Smell and taste \\
\hline Ocimum basilicum & Smell and taste & Tilia spp. & Smell \\
\hline
\end{tabular}

Table 9. Some suggested plants for The Aquatic Garden

\begin{tabular}{|c|c|c|}
\hline Latin name & Latin name & Latin name \\
\hline Acer palmatum & Equisetum ramossissium & Potamogeton panormitanus \\
\hline Acer platanoides & Geum urbanum & Potamogeton perfoliatus \\
\hline Acorus calamus & Groenlandia densa & Potentilla detommasii \\
\hline Alisma gramineum & Iris pseudacorus & Potentilla recta \\
\hline Alisma plantago-aquatica & Isolepis setacea & Potentilla reptans \\
\hline Alnus glutinosa & Lemna gibba & Primula auriculata \\
\hline Apium nodiflorum & Linum catharticum & Prunella orientalis \\
\hline Arum detruncatum var. detruncatum & Lysimachia punctata & Ranunculus gueneri \\
\hline Barbarea plantaginea & Lythrum salicaria & Ranunculus repens \\
\hline Bellis perennis & Melica penicillaris & Ranunculus sceleratus \\
\hline Blysmus compressus & Mentha spicata subsp. tomentosa & Ranunculus sphaerospermus \\
\hline Calamagrostis pseudophragmites & Myriophyllum spicatum & Ranunculus trichophyllus \\
\hline Calla palustris & Myriophyllum verticillatum & Ranunculus velutinus \\
\hline Canna indica & Nuphar lutea & Rumex crispus \\
\hline Carex halleriana & Nymphaea alba & Rumex patientia \\
\hline Carex muricata & Oenanthe aquatica & Salix alba \\
\hline Carex otrubae & Ornithogalum umbellatum & Salix babylonica \\
\hline Carex riparia & Phragmites australis & Salix caprea 'pendula' \\
\hline Ceratophyllum demersum & Phragmites communis & Scirpoides holoschoenus \\
\hline Cortaderia selloana & Platanus orientalis & Scirpus lacustris \\
\hline Crenosciadum siifolium & Polyganum bellardii & Tamarix parviflora \\
\hline Cyperus longus & Polyganum pulchellum & Tetragonolobus maritimus \\
\hline Cyperus rotundus & Polygonum amphibium & Typha angustifolia \\
\hline Dactylorhiza saccifera & Polygonum bistorta subsp. bistorta & Typha domingensis \\
\hline Eleocharis uniglumis & Polygonum lapathifolium & Utricularia vulgaris \\
\hline Epilobium hirsitum & Potamogeton crispus & Veronica anagallis-aquatica \\
\hline Epilobium minutiflorum & Potamogeton crispus & \\
\hline Equisetum arvense & Potamogeton lucens & \\
\hline
\end{tabular}

Table 10. Some suggested plants for The Rock Garden

\begin{tabular}{lll}
\hline Latin name & Latin name & Latin name \\
\hline Acantholimon ulinicum & Dianthus sp. & Onorbrychis cornuta \\
Aethionema sp. & Erodium amenum & Onorbrychis hypargyrea \\
Alyssum aurantiacum & Erodium pelargoniiflorum & Pelargonium endlicherianum \\
Anthemis cretica & Festuca spp. & Pinus mugo \\
Arabis caucasica subsp. Brevifolia & Fibigia eriocarpa & Ranunculus brevifolius \\
Arenaria sp. & Genista lydia var. lydia & Ranunculus cadmicus \\
Aster alpinus & Glacium leicarpum & Ribes orientale \\
Astragalus angustifolia & Hypericum ternatum & Sedum spp. \\
Aubrieta pinardii & Inula heterolepis & Sempervivum lspartae \\
Berberis crataegina & Iberis sempervirens & Sempervivum pisidicum \\
Berberis cretica & Juniperus excelsa & Silene compacta \\
Campanula sp. & Juniperus foetidissima & Valeriana oligantha \\
Cerastium banaticum & Marrubium sp. & Vavilovia formosa \\
Cotoneaster nummularia & Matthiola montana & Ziziphora clinopodioides \\
Daphne oleoides subsp. oleoides & Minuartia leucocephala & \\
\hline
\end{tabular}

\section{Conclusion}

Within the scope of this study, it is aimed to create a botanical garden in Isparta in the Lakes Region in a real sense. For this reason, a new design approach has been foreseen with the plan decisions that will enable SDU Botanical Garden, which is available, but not actively used except for some educational and scientific studies, for both regional and national use.

From all these suggestions,

- The right to develop and manage SDU Botanical Garden in order to be able to make structural and planting 
applications must be left to the SDU Rectorate, and the inadequacy of financing should be resolved, in this regard, the assistance and support of central and local authorities should be provided.

- A management group with different occupational groups in the field should be established to start works.

- Detailed structural and plant application sheets should be drawn for each of the plant collections in the direction of the concept plan generated from on-site observations.

- Priority should be given to plants specific to the Lakes Region in plant collections. Thus, the botanical garden will gain an identity while providing economic and ecological advantages.

- In order to draw attention to the people to the botanical garden and to raise awareness among the local people, studies on the collection of medical aromatic plants, geophyte plants, endemic and rare species which form the focus of the garden and reflect the region should be started.

- Because of the success of germinating and short-term results in geophyte plants, educational courses for the public and students to participate should be opened for some periods, garden exhibitions should be arranged and introductions should be made to the universities, municipalities and various institutions with introduction brochures.

- The public should be educated about the cultivation, collection, storage, and consumption of medicinal and aromatic plants in the region and training should be organized in this regard.

- Educational programs in the botanical garden should be organized for the students in the primary and secondary schools in the province, and contributions should be made to the education of generations who love and protect nature.

- Thanks to the training and introductions given in the botanical garden, a botanical garden, which is integrated with the local people and adopted by the local people will be created from the establishment stage.

As a result; in the new design approach, a new circulation system has been developed which can be easily reached by the users and increase the recognition of the plant collection areas. In addition, the thematic areas that increase the participation of users have been developed and the area has become more usable. In this context, Süleyman Demirel University Botanic Garden will be an important value for Turkey in terms of introducing and preserving plant diversity, conducting scientific research and educational activities, and responding to recreational needs.

\section{Acknowledgements}

This research was supported by Süleyman Demirel University with the grant number, 3797-YL-13.

\section{References}

Anonymous, 2011. Isparta Çevre Durum Raporu, Isparta, s.1-493.

Avcı, M., 2005. Çeşitlilik ve endemizm açısından Türkiye'nin bitki örtüsü. Coğrafya Dergisi, 13, 27-55.

Donaldson, J.S., 2009. Botanic gardens science for conservation and global change. 10th EMBO/EMBL Science \& Society Conference: Food, Sustainability and Plant Science: A Global Challenge, 6-7 November 2009, Heidelberg, Germany, pp. 608-613.

Hedge, I.C., 1992. A Global Survery of The Lamiaceae. Advencis in Labiatae Science, 7-18.

Karabacak, E., 2009. Türkiye'nin Avrupa-Sibirya Fitocoğrafik Bölgesindeki Salvia L. (Lamiaceae) cinsinin revizyonu. Doktora Tezi, Çanakkale Onsekiz Mart Üniversitesi, Fen Bilimleri Enstitüsü, Çanakkale.

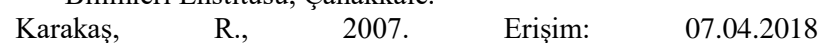
http://shakayik.blogcu.com/osmanlida-lale-kulturu/2517786

Konaklı, N., 2003. Arboretum kavramı ve Selçuk Üniversitesi kampus alanı için Arboretum oluşturulması üzerine bir araştırma. Yüksek Lisans Tezi, Selçuk Üniversitesi, Konya, Turkey.

Kılıçarslan, N., Dönmez, Ş., 2016. Göller bölgesinde doğal olarak yetişen soğanlı bitkilerin peyzaj mimarlığında kullanımı. Süleyman Demirel Üniversitesi Orman Fakültesi Dergisi, 17(1): 73-82.

Kumble, P.A., Houston, C.C., 2009. The elements of a conservation botanic garden for ecotourism: Belize Botanic Garden as a case study. Journal of Landscape Studies, 2:1-15.

Oldfield, S., 2009. Botanic gardens and the conservation of tree species. 10th EMBO/EMBL Science \& Society Conference: Food, Sustainability and Plant Science: A Global Challenge, 67 November 2009, Heidelberg, Germany, pp. 581-583.

Özçelik, H., Dutkuner, İ., Balabanlı, C., Akgün, İ., Gül, A., Karataş, A., Kılıç, S., Deligöz, A., 2006. Süleyman Demirel Botanik Bahçesinin tanıtımı. Suleyman Demirel Üniversitesi Fen Bilimleri Enstitüsü Dergisi, 10(3): 352-373.

Ünlü, N., 2016. Botanik bahçeleri planlama ve tasarım ilkeleri; Süleyman Demirel Üniversitesi Botanik Bahçesi örneği. Yüksek Lisans Tezi, Süleyman Demirel Üniversitesi, Fen Bilimleri Enstitüsü, Isparta.

Var, M., Karaşah, B., 2010. Botanik bahçelerinin kullanıcılara sağladığı eğitsel ve rekreatif imkanlar: Türkiye ve dünya'dan örnekler. III. Ulusal Karadeniz Ormanc1lık Kongresi, Vol. IV, 20-22 Mayis 2010, Artvin, Türkiye, s. 1467-1477.

Ward, C.D., Parker, C.M., Shackleton, C.M., 2010. The use and appreciation of botanical gardens as urban green spaces in South Africa. Urban Forestry and Urban Greening, 9:49-55.

Williams, S.J., Jones, J., Gibson, J.M., Clubbe, C., 2015. Botanic gardens can positively influence visitors' environmental attitudes. Biodiversity and Conservation, 24:1609-1620.

Willison, J., 1997. Botanic gardens as agents for social change. In Kings Park and Botanic garden conservation into the 21st century. Proceedings of the Fourth International Botanical Gardens Conservation Congress, 25-29 September 1997, Perth, Australia, pp. 25-29. 